\title{
泥水加圧シールドの切羽の安定性と掘削管理

\author{
FACE STABILITY AND CONTROL OF EXCAVATION \\ IN THE MUD SHIELD METHOD
}

\author{
山崎 廣 宣* \\ By Hironobu YAMAZAKI
}

\section{1. 研究の目的}

泥水シールド工法は日本で開発された工法で，都市卜 ンネルの建設に多用されている. 現在のところ,この研 究開発は経験的知識に依存し, 科学的な解析が不十分の ように見受けられる．泥水シールド工法は，粘土シルト 奬濁液を使うスラリーシールドであり, その問題点は, 以下のと抢りと考える.

第 1 は，切羽崩壊を防ぐ泥水の特性と切羽保持機構の 解明である. 泥水の特性は石油さく井で, また, 切羽保 持機構は地中壁工法で研究されたが, 目的の違いから, その成果をそのまま泥水シールドに適用し得ない，それ ゆえ, この工法に適応した泥水の特性を研究し, その結 果に基づいて，個々の現場条件に適合した泥水の示方を 決定し得ることが望ましい。

第 2 は，掘削管理の問題である. 泥水シールドは, 掘 削土砂を流体輸送し, 地表面のプラントで処理する.そ れゆえ, 直接切羽を視覚で観察し得ず, 何らかの間接手 段で掘削量を測定し, 切羽の状況を察知することが施工 管理上必要である.

第 3 は, シールド機械の問題である. 泥水シールド機 械の構造様式は, 掘削地層に対応して経験的に決定され る. 機構上の重要点は, 軸受部の防水シールおよびスキ ンプレートとセグメント裏面を密閉するテールシールで ある.軸受部シールは，現在一流メーカーならば满足な ものを造る。テールシールはワイヤー型構造が開発さ

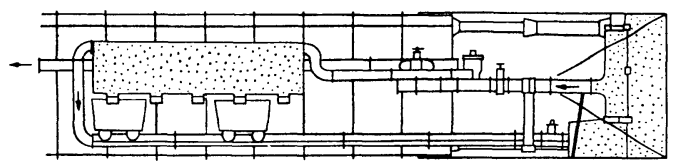

図一1 James H. Greathead の考えた水压シールド1)

* 正会員 工博 鉄建建設 (株) 常務取締役
れ, 泥水圧 $4 \mathrm{kgf} / \mathrm{cm}^{2}(392 \mathrm{kPa})$ まで実用化されている. それゆえ，第 3 の問題は本論文で取り扱わず，第 1 およ び第 2 の問題についてのみ考察する.

\section{2. 泥水シールドの歴史}

\section{（1）実現までの歴史}

圧気シールドの切羽面は垂直であるから, 切羽に圧気 を作用させると，上部で地下水圧とバランスすれば，下 部でバランスを失い, 地下水の流入をみる. これは均一 モデル層の場合で，実在する地層は複雑多岐であり， 圧気が切羽面に有効に作用する場合も数多くある. しか し, 透水係数大で, かつ, 均一な地層の場合は, 圧気の 噴出, または地下水の流入を生じ, 切羽が自立せず崩壊 する.

このようなことから水を利用して地下水の流入を防止 するシールドが考えられた．水圧シールドの発想であ る. 1884 年イギリスの James H. Greathead は, 図一 1 に示寸水圧シールドを考案しパテントを申請した1). Veasey によれば，水で切羽を保持し得ない点から断念 されたといら²)。その後 Vering, Haag, Comob が同様 の構想を提案した. いずれにせよ, 非粘着性の切羽は水 で保持できない点から実現しなかったと推察される.

ベントナイトが石油さく井に利用され，スラリーとし ての高性能が認められるとともに, 土木部門にも導入さ れ，1950 年代に地中壁工法が開発された. このベント ナイトを水圧シールドに導入したのがベントナイト・シ ールドである. Schneidereit (1960) が最初にパテント 申請した. 彼の提案は, 粘着性地層では水, 非粘着性地 層ではベントナイト，またはそれに類似の泥水を加圧し て切羽を保持する方式である. 次いで Lorenz (1962) は, ベントナイトその他のチキソトロピックな液体で切 羽の安定と目づまり (Sealing) を行い, 泥水圧で土圧お 
よび水圧に対抗させようとした．Bartlett（1964）の提 案は特許文面には明確に説明されていないが，Veasey の解説によるとかきまぜると液体となり，放置すればゼ リー状になるチキソトロピック性の完全な利用である. もしベントナイト・スラリーがチキソトロピックなら ば，掘削停止中はゲル化して切羽を完全に保持すること になる、ベントナイト・シールドの誕生である. 実際 の施工例としては 1968 営団地下鉄 8 号線神田川シール ドエ区のパイロット・トンネル, 1972 イギリス New Cross のベントナイト・シールド, 1974 ハンブルグの Hydro shield，また 1975 イギリス Warrington のベン トナイト・シールドがある.

日本においては，ベントナイトを使用するとき，その 経済性および残土処理の規制から，その使用におのずか ら制約があり，その制約を打破する意味から粘土シルト 泥水を使う泥水シールド工法が開発された。

\section{（2） 泥水シールドの可能性}

泥水シールド工法が可能であるためには, 土圧および 水圧を保持する泥水圧とその圧力を切羽へ伝達する泥膜 の形成が必要である. いま, この可能性をすでに発表さ れた文献により調べてみよう。喜田は細粒土は化学作 用, 粗粒土は目づまり効果により泥膜が形成されるとし $た^{3)}$. Rogers は次の 2 例を述べている ${ }^{4)}$. 第 1 は石油さ く井現場で使用されている泥水を分析したところ，モン モリロナイトは含まれず，土粒子は $0.1 \mu \mathrm{m} \sim 1.19 \mathrm{~mm}$ の範囲に分布し, $7 \sim 8 \mathrm{wt} . \%$ が $2 \mu \mathrm{m}$ 以下のコロイドで あったが，API テストの透水量は $21 \sim 23 \mathrm{~m} l$ と良質の 泥水であった. 第 2 の Gates と Bowie は 20 の現場 と 40 の試験室泥水から土粒子の粒度分布を調査し, 上 限および下限を見出した. 比較的良好な泥水の粒度分布 として,コロイド (2 $\mu \mathrm{m}$ 以下) $42 \sim 88 \%$, シルト 7〜 46\%, 砂 5 13\% の範囲を示した. Boyes は透水性地 層の逸水について 5 , 有効径の $1 / 10$ より大きい粒子は その地層へ浸透せず，また間隙径の $1 / 3$ 以上の粒子はそ の間隚を通過できないとの仮定に基づいて, 逸水を物理 的な目づまり問題と考えた．以上のことから地層の間隙 に目づまり効果が起こるような粘性と粒度分布をもつ泥 水を使用すれば泥膜が形成され泥水加圧シールド工法は 可能であると推定される.

\section{3. 泥水の性質と効果}

\section{（1） 粘土シルト泥水の特性}

今回の研究で, 実際の地盤を構成する代表的なものと して, 通称水川台粘土を用いた. 水川台粘土は洪積層に
属し，東京上部䃏層の下部にある固結シルト質粘土であ る. このシルト質粘土は, 営団地下鉄 8 号線の泥水シー ルド用泥水の材料として使われた. 水川台粘土泥水の特 性は以下のとおりである.

a）粒度分布および比表面積

氷川台粘土の粒径加積曲線を図一2に示す. 0 24 $\mu \mathrm{m}$ の直径の粒子が $82 \%$ を占め, 泥水用材料として良好で ある.

図一2 は各種の測定方法および測定計器による結果を 示す. ストークス粒径は JIS 規格沈降試験, 光透過式 はセイシン SKN-100 の光透過法, セディグラフは島津 製作所 $5000 \mathrm{D}$ のX線による粒径解析，オムニコンは 島津製作所オムニコン FAS-II による 光学顕微鏡画像 解析の粒径分布である.この図から, 分散剂 (ヘキサメ タリン酸ソーダ $0.2 \%$ 溶液) の使用による凝集粒子の分 解が推定される.

次に, 比表面積の測定結果を 表一1 に示す. 図一2の 曲線 (5)の粒度分布から計算した氷川台土粒子の平均比 表面積は $18200 \mathrm{~cm}^{2} / \mathrm{g}\left(1820 \mathrm{~m}^{2} / \mathrm{kg}\right)$ となり, 沖積層の 小菅および手賀沼試料に比較して，粒子の電気化学的性 質が優れているといえる.

b) 実験結果

泥水シールド用泥水安定液の設計に要する基礎資料を 得るために沈降試験を 3 種類, 沈降推積ベット透過試 験, イールド・バリュー試験, および塑性粘性試験を行 った.

沈降試験は内径 $99.4 \mathrm{~mm}$ のメスシリンダー, 初期高 $H_{0}=20 \sim 100 \mathrm{~cm}$, 泥水密度 $\rho_{L}=1.01 \sim 1.35 \mathrm{~g} / \mathrm{cm}^{3}(1010$

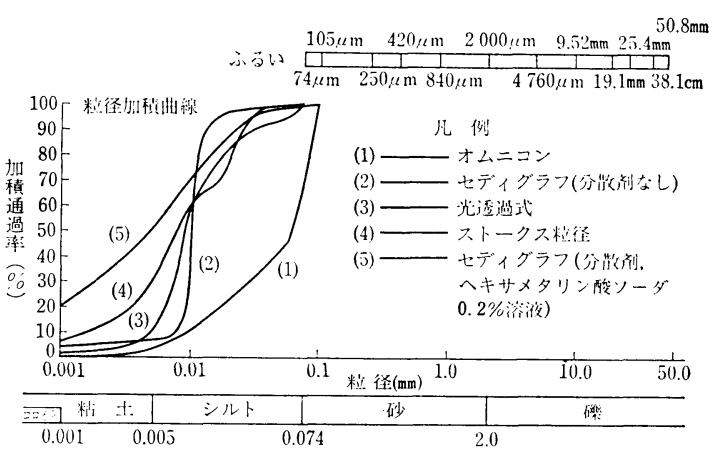

図一2 水川台粘土シルト泥水の測定方法別 粒径加積曲線

表一1 泥水シールド各現場の土粒子の比表面積

\begin{tabular}{|c|c|c|c|c|c|}
\hline & 試 & 料 & 名 & 比 & $\begin{array}{c}\text { 比表面積 } \\
\left(\mathrm{g} / \mathrm{cm}^{2}\right)\end{array}$ \\
\hline 1 & 水 & 川 台 & $24 \mu \mathrm{m}$ & 2.56 & 18600 \\
\hline 2 & & $"$ & $44 \mu \mathrm{m}$ & 2.57 & 13650 \\
\hline 3 & & $"$ & $74 \mu \mathrm{m}$ & 2.60 & 11370 \\
\hline 4 & 小 & & 管 & 2.55 & 10020 \\
\hline 5 & 手 & 賀 & 沼 & 2.54 & 7670 \\
\hline
\end{tabular}


$\left.\sim 1350 \mathrm{~kg} / \mathrm{m}^{3}\right)$ 目盛りは $1 \mathrm{~mm}$ 間隔で目視により測定 した. その結果 $\rho_{L}=1090 \mathrm{~kg} / \mathrm{m}^{3}$ までが干涉沈降, $\rho_{L}$ $=1090 \sim 1190 \mathrm{~kg} / \mathrm{m}^{3}$ 間がネットワーク沈降，それ以上 が圧縮沈降と区分された. 泥水密度に対応した初期沈降 速度 $V_{i}$ の一例を図一 3 に示寸.

泥水密度を一定とし高さを変えた沈降試験から, 泥水 密度が同じときの沈降曲線の相似性が成立した。また， 泥水中に含有される土粒子質量を一定とし初期高さを変 えた沈降試験から, 吉岡 ${ }^{6}$, Shannon ${ }^{7)}$ の指摘と異なり, 図一4 のごとく, 初期の泥水濃度により最終沈降ベット 高が変わり, 初期濃度が高い場合, ベット高は低いとい う結果が得られた。

吉岡はベット高が土粒子質量の関数であるとし，ま

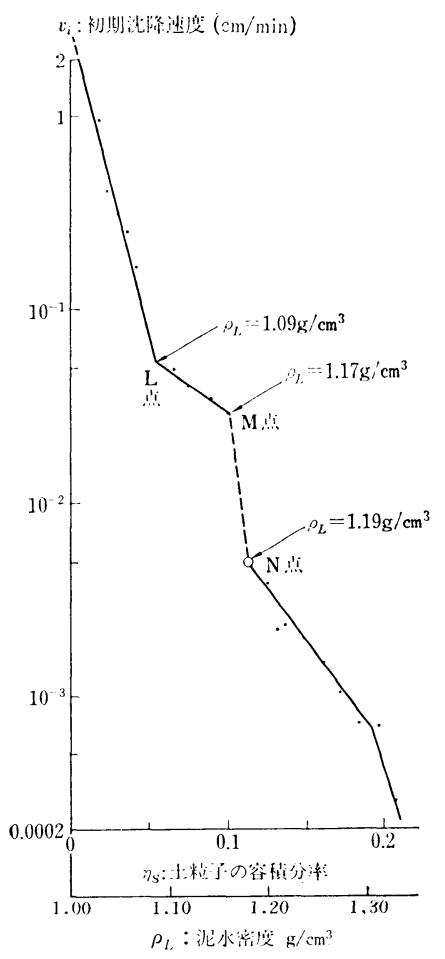

図一3 初期沈降速度と泥水濃度の関係 (容器经 $99.4 \mathrm{~mm}$ ) たガラス王 (平均径 $67 \mu \mathrm{m})$ を用いた実 験から Shannon は 一定量のガラス王の 懸濁液はその濃度に 関係なく，一定高さ に推積することを示 した. それゆえ, 水

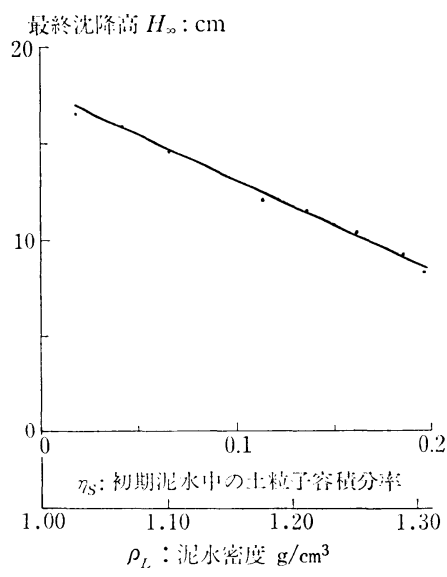

図一4 泥水中の土粒子量を一定とし 泥水濃度を変えたときの沈降 ベットの高さ

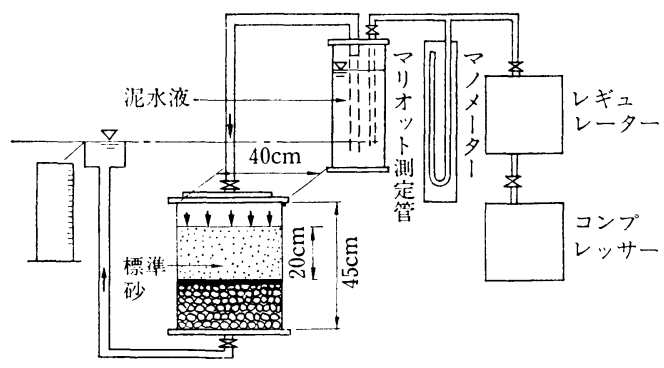

図一5 泥膜透水試験用の大型モールド汇過試験装置
表一2 沈降ベットの透水試験結果表

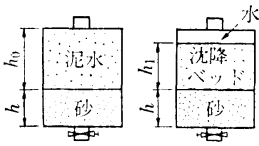

\begin{tabular}{lrr|c|c|c}
\hline 泥 水 密 & $\rho_{L}\left(\mathrm{~g} / \mathrm{cm}^{3}\right)$ & 1.11 & 1.19 & 1.30 \\
底 面砂の高さ & $h(\mathrm{~cm})$ & 10.4 & 11.7 & 9.5 \\
底 面砂の透水係数 & $k(\mathrm{~cm} / \mathrm{s})$ & $1.5 \times 10^{-2}$ & $2.1 \times 10^{-2}$ & $1.3 \times 10^{-2}$ \\
沈降 たットの高さ & $h_{1}(\mathrm{~cm})$ & 8.9 & 13.3 & 14.7 \\
泥 水の 初 期 高 & $h_{0}(\mathrm{~cm})$ & 15.6 & 16.3 & 16.5 \\
泥水中の土粒子重量 & $(\mathrm{g})$ & 215.0 & 388.0 & 620.0 \\
\hline
\end{tabular}

\begin{tabular}{|c|c|c|c|c|c|c|}
\hline & \multicolumn{2}{|c|}{$\rho_{L}=1.11$} & \multicolumn{2}{|c|}{$\rho_{L}=1.19$} & \multicolumn{2}{|c|}{$\rho_{L}=1.30$} \\
\hline $\begin{array}{l}\text { 泥水压力 } \\
\left(\mathrm{kgf} / \mathrm{cm}^{2}\right)\end{array}$ & $\begin{array}{c}\text { ヘッッ高 } \\
(\mathrm{cm})\end{array}$ & $\begin{array}{l}\text { 沪 過 量 } \\
\text { (cc/分) }\end{array}$ & 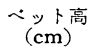 & $\begin{array}{l}\text { 洰 過 量 } \\
\text { (cc/分) }\end{array}$ & $\begin{array}{c}\text { テット高 } \\
(\mathrm{cm})\end{array}$ & $\begin{array}{l}\text { 沪過 舅 } \\
\text { (cc/分) }\end{array}$ \\
\hline 0 & 8.9 & 0 & 13.3 & 0 & 14.7 & 0 \\
\hline 0.1 & 8.9 & 0 & 13.2 & 0 & 14.7 & 0 \\
\hline 0.2 & 8.9 & 0 & 13.2 & 0 & 14.7 & 0 \\
\hline 0.3 & 8.9 & 0 & 13.2 & 0 & 14.7 & 0 \\
\hline 0.4 & 8.8 & 13.0 & 13.2 & 0 & 14.7 & 0 \\
\hline 0.5 & 8.6 & 12.0 & 13.2 & 0 & 14.7 & 0 \\
\hline 0.6 & 8.6 & 8.0 & 13.0 & 5.2 & 14.6 & 3.0 \\
\hline 0.7 & 8.4 & 7.7 & 12.9 & 4.6 & 14.5 & 2.8 \\
\hline 0.8 & 8.2 & 7.3 & 12.8 & 4.0 & 14.4 & 2.6 \\
\hline 0.9 & 8.1 & 7.0 & 12.7 & 4.0 & 14.3 & 2.2 \\
\hline 1.0 & 7.9 & 7.0 & 12.6 & 3.3 & 14.2 & 1.9 \\
\hline
\end{tabular}

川台泥水は濃度により結合体の単位が変化すると推定さ れる。

沈降ベット透過試験は 図一5に示す大 型モールド沪過試験装置と同じで，モー ルド径 $100 \mathrm{~mm}$ のものを用いた。その結 果を 表一2 亿示す. 泥水を $1.0 \mathrm{kgf} / \mathrm{cm}^{2}$ $(98 \mathrm{kPa})$ で加圧後撤去すると，いずれ の場合も砂の境界面に 9 12 $\mathrm{mm}$ の密度 の高い泥膜が形成されていた。

イールド・バリューおよび塑性粘性の 測定は Fann Visco-meter Model 35 お よび日本精器製レオメーターIR-200で 行われた. $\rho_{L}=1350 \mathrm{~kg} / \mathrm{m}^{3}$ までは VG メーター, それ以上は IR-200 で測定さ れた．流動曲線の一例が図一6であり， ビンガム流動を示す. 図一7, 図一8 に泥 水密度とイールド・バリューおよび塑性 粘性の関係をそれぞれ示す.これらの值を用いて, 後に 示すように泥水の設計を行うことになる.

\section{c）考察}

Michaeles はカオリンを8), 北浦はカオリンおよび硫 酸バリウムその他を使い9), それらの物質がフロックを 形成し, 弱いせん断力下ではフロックがさらに集結して Aggregate を形成し, 強いせん断力下では, フロック 単位になることを見出した. 氷川台泥水も図一2の粒度 曲線から一次粒子が凝集してフロックを形成していると 推定された。いま, 水川台フロックも Aggregate を形 

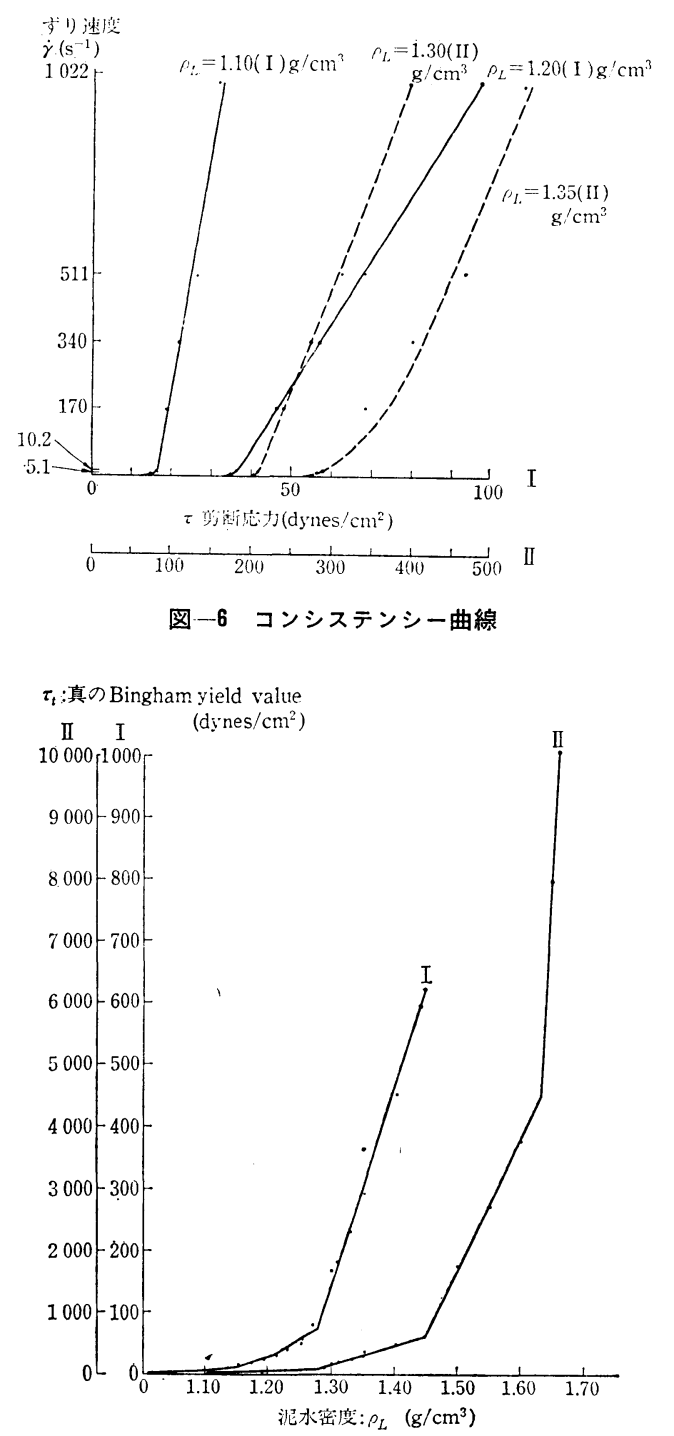

図一7 泥水密度と Yield Value の関連

成するとして Michaeles の方法に従い，均一球の干涉 沈降に適用される Richardson \& Zaki の沈降式で計算 すると Aggregate の直径は, $68.4 \mu \mathrm{m}$, 密度 $\rho_{A}=1.156$ $\mathrm{g} / \mathrm{cm}^{3}\left(1156 \mathrm{~kg} / \mathrm{m}^{3}\right)$ となる.

Aggregate は沈降中その形状を保持するが, 沈降堆 積すると崩壊し, フロックのみの集積物になると仮定す る. Michaeles の方法により沈降ベットからフロック密 度を計算した.フロックはほぼ球形であるから, 詰め込 み度は Shannon の実測值よりフロック容積分率を 0.64 とする. 沈降ベットの実測データの計算結果が図一9で あり, 図中の $C_{F S}$ はフロック容積分率と土粒子容積分 率の比である.

沈降ベットの透過試験からフロックを単位粒子として Kozeny-Carman の式よりフロック直径が計算できると

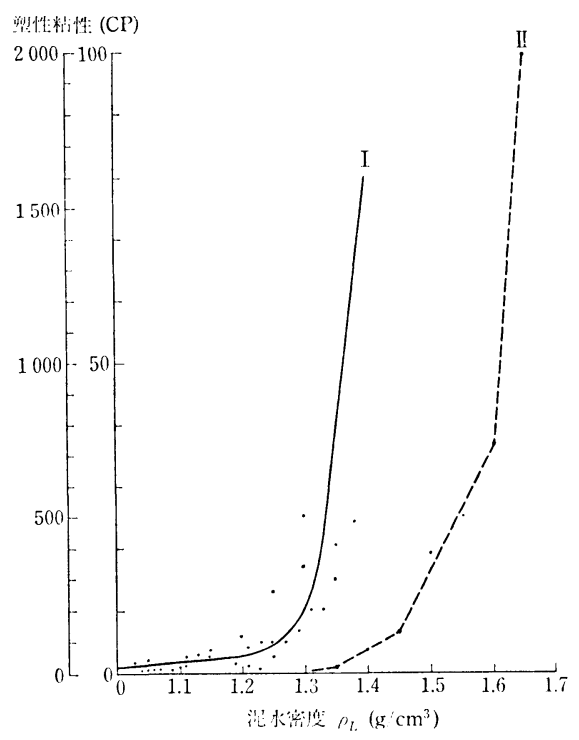

图一8 泥水密度と塑性粘性の関連

表一3 泥膜の透水係数およびフロック直径

$\mathrm{F}$ 部 $: 10 \mathrm{~mm}$ の泥膜層

$\mathrm{F}$ 部 $n_{S}: 10 \mathrm{~mm}$ の浔膜層の土粒子容皘分率

$\mathrm{F}$ 部 $n_{F}: 10 \mathrm{~mm}$ の泥膜層のフロック容積分率

\begin{tabular}{|c|c|c|c|c|c|c|}
\hline $\begin{array}{c}\text { 泥水密度 } \\
\rho L \\
\left(\mathbf{g} / \mathrm{cm}^{3}\right)\end{array}$ & $\begin{array}{c}\text { 泥水圧 } \\
\left(\mathrm{kgf} / \mathrm{cm}^{2}\right)\end{array}$ & 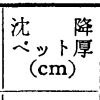 & $\begin{array}{c}F \text { 部 } \\
n_{S}\end{array}$ & $\begin{array}{c}\mathrm{F} \text { 部 } \\
n_{F}\end{array}$ & $\begin{array}{c}F_{\text {透水係部 }} \\
k \\
(\mathrm{~cm} / \mathrm{s})\end{array}$ & $\begin{array}{l}\text { ᄀロッック } \\
\text { 徝 }_{d_{F}(\mu \mathrm{m})}\end{array}$ \\
\hline \multirow{8}{*}{1.11} & 0 & 8.9 & 0.115 & 0.64 & - & - \\
\hline & 0.4 & 8.8 & 0.126 & 0.64 & $6.1 \times 10^{-5}$ & 136 \\
\hline & 0.5 & 8.6 & 0.149 & 0.64 & $1.4 \times 10^{-5}$ & 110 \\
\hline & 0.6 & 8.5 & 0.161 & 0.64 & $4.3 \times 10^{-6}$ & 67 \\
\hline & 0.7 & 8.4 & 0.172 & 0.64 & $3.2 \times 10^{-6}$ & 64 \\
\hline & 0.8 & 8.2 & 0.195 & 0.64 & $2.5 \times 10^{-6}$ & 59 \\
\hline & 0.9 & 8.1 & 0.207 & 0.64 & $2.0 \times 10^{-6}$ & 53 \\
\hline & 1.0 & 7.9 & 0.230 & 0.64 & $1.7 \times 10^{-6}$ & 49 \\
\hline \multirow{7}{*}{1.19} & 0 & 13.3 & 0.139 & 0.64 & - & - \\
\hline & 0.5 & 13.2 & 0.152 & 0.64 & - & - \\
\hline & 0.6 & 13.0 & 0.180 & 0.64 & $2.4 \times 10^{-5}$ & 184 \\
\hline & 0.7 & 12.9 & 0.194 & 0.64 & $4.5 \times 10^{-6}$ & 80 \\
\hline & 0.8 & 12.8 & 0.208 & 0.64 & $2.2 \times 10^{-6}$ & 56 \\
\hline & 0.9 & 12.7 & 0.222 & 0.64 & $1.7 \times 10^{-6}$ & 49 \\
\hline & 1.0 & 12.6 & 0.235 & 0.64 & $1.0 \times 10^{-6}$ & 38 \\
\hline \multirow{6}{*}{1.30} & 0 & 14.7 & 0.200 & 0.64 & - & - \\
\hline & 0.6 & 14.6 & 0.220 & 0.64 & $1.6 \times 10^{-5}$ & 150 \\
\hline & 0.7 & 14.5 & 0.240 & 0.64 & $3.1 \times 10^{-6}$ & 66 \\
\hline & 0.8 & 14.4 & 0.260 & 0.64 & $1.6 \times 10^{-6}$ & 48 \\
\hline & 0.9 & 14.3 & 0.280 & 0.64 & $9.1 \times 10^{-7}$ & 36 \\
\hline & 1.0 & 14.2 & 0.300 & 0.64 & $6.1 \times 10^{-7}$ & 29 \\
\hline
\end{tabular}

Michaeles は提案した ${ }^{10)}$. 沈降ベットは水流の通過によ り沪材面上に $10 \mathrm{~mm}$ の密度の高い泥膜が形成され, か つ,他のベット部分は堆積時そのままであると仮定する. 計算の結果水圧によりフロック径は 表一3 のごとく 29 〜184 $\mu \mathrm{m}$ と変わり, 加圧が高いときフロック径は小と なる.

前記沈降試験の結果, Aggregate の直径は $68.4 \mu \mathrm{m}$ であり,これ以上の直径が計算されたことから, 㳫川台 
粘土泥水は沈降中 Aggregate を形成せず, フロックの まま干渉沈降するといえそうである。

泥水密度 $\rho_{L}=1.09 \mathrm{~g} / \mathrm{cm}^{3}\left(1090 \mathrm{~kg} / \mathrm{m}^{3}\right)$ で干涉沈降か らネットワーク沈降に変わるが, 後藤の方法に倣い' ${ }^{11)}$, 初期沈降速度とフロック構造の関連を考察する.いま, 図一9 の沈降ベット中の土粒子容積分率とフロック密度 との関係が泥水中でも同様に成立すると仮定する. 泥水 密度 $\rho_{L}=1.09 \mathrm{~g} / \mathrm{cm}^{3}\left(1090 \mathrm{~kg} / \mathrm{m}^{3}\right)$ で初めてネットワー クが完成し, そのときフロックは最疎組合せの単純立方 型 0.52 とすれば, 図一9よりフロック密度 $\rho_{F}=1.156$ $\mathrm{g} / \mathrm{cm}^{3}\left(1156 \mathrm{~kg} / \mathrm{m}^{3}\right)$ から, そのときの泥水密度は,

$$
\begin{aligned}
\rho_{L} & =1.156 \times 0.52+1 \times 0.48 \\
& =1.081 \mathrm{~g} / \mathrm{cm}^{3}\left(1081 \mathrm{~kg} / \mathrm{m}^{3}\right)
\end{aligned}
$$

となる. 図一3 での次の変化点は $\rho_{L}=1.17 \mathrm{~g} / \mathrm{cm}^{3}(1170$ $\mathrm{kg} / \mathrm{m}^{3}$ ) である. 図一9 よりこれに対応するフロック密 度は $\rho_{F}=1.275 \mathrm{~g} / \mathrm{cm}^{3}\left(1275 \mathrm{~kg} / \mathrm{m}^{3}\right)$ である.いま，こ の点が六方充填 0.605 にフロックが集積するとすれば, 泥水密度は計算上 $1.166 \mathrm{~g} / \mathrm{cm}^{3}\left(1166 \mathrm{~kg} / \mathrm{m}^{3}\right)$ となる. 次の変化点は $\rho_{L}=1.19 \mathrm{~g} / \mathrm{cm}^{3}\left(1190 \mathrm{~kg} / \mathrm{m}^{3}\right)$ である. い ま, これを 0.64 充填とし, 図一9 より $\rho_{F}=1.303 \mathrm{~g} /$ $\mathrm{cm}^{3}\left(1303 \mathrm{~kg} / \mathrm{m}^{3}\right)$, よって, フロック密度 $\rho_{F}=1.194 \mathrm{~g} /$ $\mathrm{cm}^{3}\left(1194 \mathrm{~kg} / \mathrm{m}^{3}\right)$ となる. 以上の事実から，泥水中で も, 沈降ベット中でも, 同一土粒子容積分率で同一のフ ロック密度が形成され, 初期沈降速度の変化点図一3の L. M. $N$ はそれぞれフロックの充填構造と密接な関係 があると判断される. 図一9より土粒子容積分率が増大 すると, フロック密度が増大し, 表一3 よりフロック径 が減少するのがわかる.

均一球の 0.52 立方充填では, 球の接点は 6 個, 0.605 六方充填で接点は 8 個である. 鉛の散弾の実験から, 充 填 0.56 で平均 7.3 個, 0.64 で平均 10 個である ${ }^{12)}$. 接 触数の増大は摩擦抵抗の増加となり, フロック密度の増

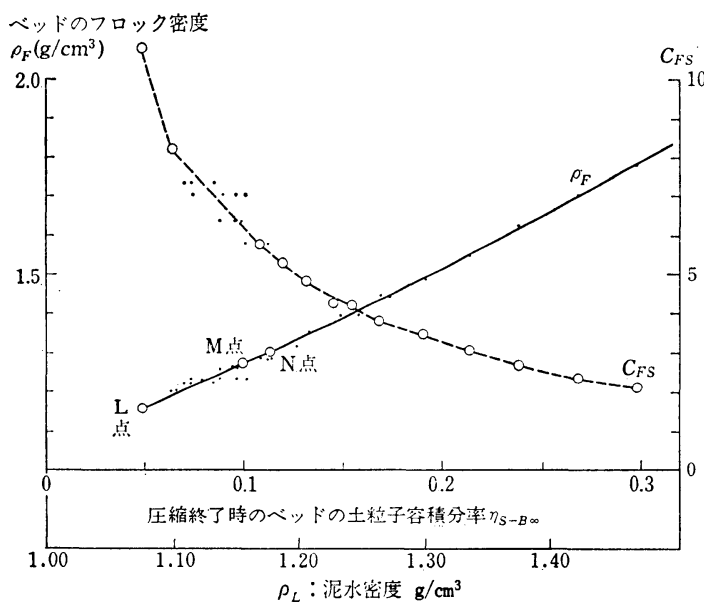

図一9 沈降ベットのブロックの密度および 土粒子との容樌比

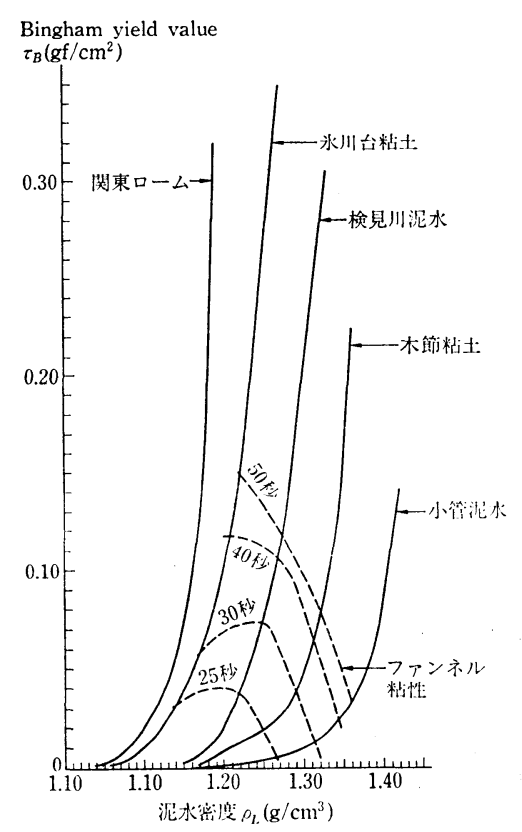

图一10 程々の泥水の Bingham Yield Value

大は, 強度の上昇から抵抗力の増大となるであろう．泥 水濃度の増大とともに，イールド・バリューの増加を示 す図一7 の傾向をこのような考え方で理解し得る.

以上の考察から, 粘土シルト泥水のビンガム流動とし ての特性は, 懸濁土粒子のフロック化能力に影響され, 同一泥水密度でも, 土粒子の性質により, 流動特性が大 幅に変化することになると思われる，その実例を図一10 に示す.

\section{（2）泥膜}

a) 泥膜の形態

図一5 に示す試験装置を用いた各種の地層, および泥 水の沪過試験の結果は, 写真一1, 2, 3 に示す泥膜形成, 中間, 貫入の 3 状態に分類される.これは, MüllerKirchenbauer の示した分類と一致している ${ }^{13)}$. 泥膜形 成機構の研究は, 泥膜形成と貫入の 2 状態を考察すれば 十分である。

泥膜形成による水圧の変化は, ダルシーの法則から導 くことができる. 試験地層の断面積 $A$, 長さ $l$, 透水係 数 $k$, 清水加圧時の透過流量 $Q$, 泥水を沪過して泥膜が 形成されたときの沪過流量を $Q^{\prime}$ とすれば，泥膜による 圧力低下 $\Delta P$ は

$$
\Delta P=\frac{l}{A k}\left(Q-Q^{\prime}\right)
$$

すなわち, 泥膜は圧力 $\Delta P$ で地層を押圧する. $\Delta P / P$ を 分率で表わし，泥膜の有効性の目安として沪過限界と名 付ける.

b）泥膜形成機構 


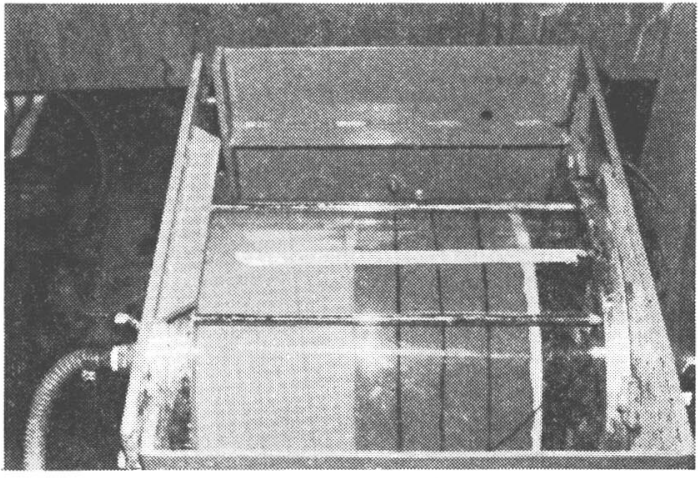

写真一1 泥膜形成状驡

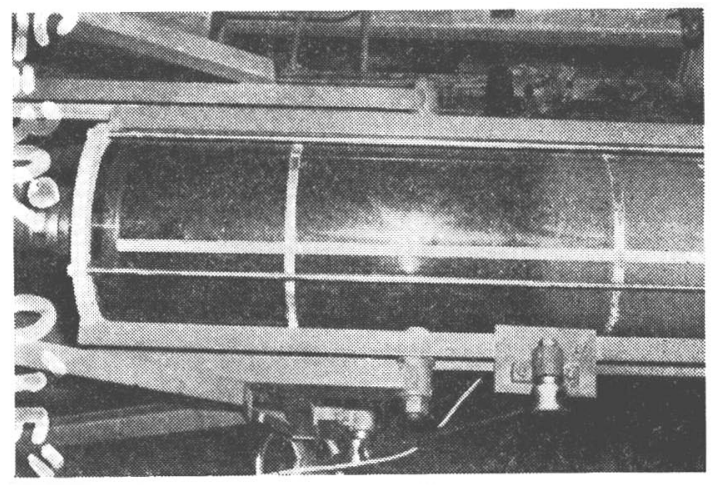

写真 -2 中間 状態

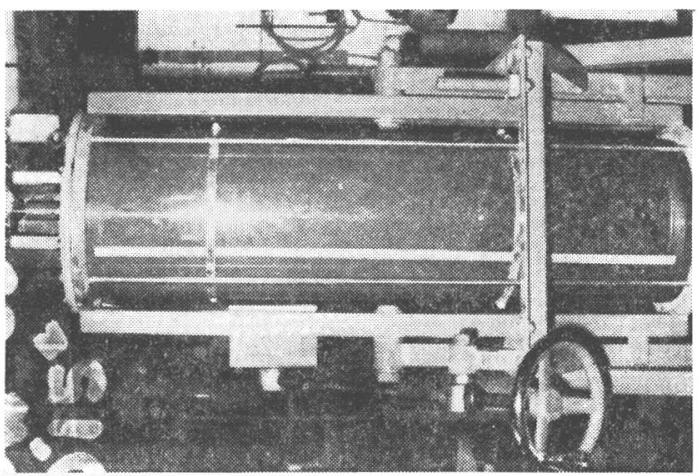

写真一3 貫入状態

沪過試験の結果の一例を 図一11 に示す。これは，泥 膜形成の場合であり，沪過開始後ただちに泥膜が形成さ れ, 時間の経過とともに, 泥膜は密となり, 透水性は減 少する. 泥膜形成の場合は 1 2 秒で沪過量はピークに 達し，以後急減する. 泥水は汇過材表面で土粒子を把握 され，沪過水は清浄水となる.

一方，貫入状態のときの試験結果は，ピーク時の流量 が $6 \sim 10$ 秒間続き，以後下降線をたどる．また，中間状 態では, 泥膜形成のときと比較して下降が 1 2 秒遅れ て始まる．貫入状態では，ピークに達するまで貫入が続 き, 泥水の粘性によってバランスがとれ，次いで流量の

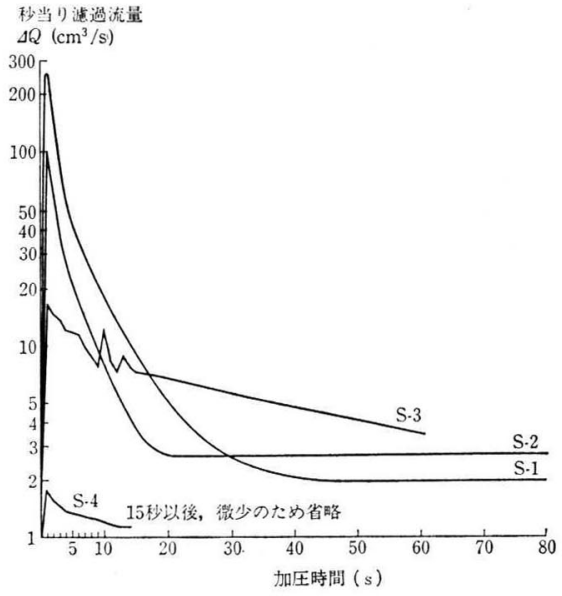

図一11 沪過流量の推移

減少が始まる.

すなわち, 泥膜形成は目づまり効果, 貫入は粘性効果 によるものである.

この目ゔまり効果を確認するために，同様の装置で実 験を行った. 実際の対象地層の粒径は $2.0 \sim 10.0 \mathrm{~mm}$ の 磷層でその 透水係数は $k=4.5 \mathrm{~cm} / \mathrm{s} \sim 12 \mathrm{~cm} / \mathrm{s}$ である.

試験用泥水は千葉の手賀沼粘土および氷川台粘土シル 卜泥水でこの泥水が完全に逸泥寸るまで密度を下げこれ を基本泥水とした. この基本泥水に各量の砂を添加し， 実験用泥水とした.この結果を一覧表にまとめたものが 表一4である.

この結果から

a. 対象地層の粒径加積曲線の $D_{20}$ の $1 / 3$ と泥水中 に含まれる土粒子の最大径を比較すると目づまり効果に より，泥膜が形成された 6 例すべて

$D_{20} / 3<$ 泥水中の土粒子の最大径

の場合である.この条件が満足された泥水 B-3 の場合 のみ, $0.2 \mathrm{kgf} / \mathrm{cm}^{2}$ で泥膜形成, $0.5 \mathrm{kgf} / \mathrm{cm}^{2}$ で逸水して いる. しかし B-3 の砂分添加は粗砂 $3 \%$ であり, 量が 少ないためのように思われる，また，泥膜形成実験の結 果からも泥水中の土粒子の最大径が $D_{20} / 3$ よりも大きい と，泥水は形態-I の完全な泥膜を形成する．逆に土粒 子最大径の方が小さいと，地層へ貫入し，形態-3 とな って泥膜を形成している.

c）泥膜に対する圧力の効果

圧力効果の試験地層は砂碩層, 透水係数 $k=2.6 \sim 3.8$ $\mathrm{cm} / \mathrm{s}$, 間隚比 0.50 である. 氷川台泥水の泥水密度 $\rho_{L}=$ $1.23 \mathrm{~g} / \mathrm{cm}^{3}\left(1230 \mathrm{~kg} / \mathrm{m}^{3}\right)$ を基本泥水とし, 図一12 亿示 寸砂分を添加して沪過試験を行う．砂添加量の増加とと もに目づまり効果が現われ，沪過量は減少する. 一方, 泥水圧の上昇とともに沪過量減少し, 有効な泥膜が形 成される.すなわち，目べまり効果により形成された泥 


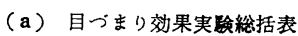

\begin{tabular}{|c|c|c|c|c|c|c|c|c|c|c|}
\hline & 泥 水 & 名 & $\begin{array}{c}k \\
(\mathrm{~cm} / \mathrm{s})\end{array}$ & 細 砂 & 中 砂 & 粗 砂 & $\begin{array}{c}\text { 密度 } \rho_{L} \\
\left(\mathrm{~g} / \mathrm{cm}^{3}\right)\end{array}$ & $\begin{array}{c}\text { 沪 過 量 } \\
(\mathrm{cc} / \mathrm{s})\end{array}$ & $\begin{array}{c}\text { 最大径: } \frac{D_{20}}{8} \\
(\mathrm{~mm})\end{array}$ & 形 態 \\
\hline \multicolumn{2}{|c|}{ 手賀沼粘土 } & $A-1$ & 12 & 4 & - & - & 1.20 & $0.7 \sim 1.3$ & $1.8: 0.25$ & 2 \\
\hline \multicolumn{2}{|c|}{ " } & A- 2 & 12 & 3 & - & - & 1.18 & $1.3 \sim 2.2$ & $1.8: 0.25$ & 2 \\
\hline \multicolumn{2}{|r|}{$"$} & A- 3 & 12 & 4 & - & - & 1.15 & $\infty$ & $1.8: 0.25$ & - \\
\hline \multicolumn{2}{|r|}{ 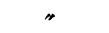 } & A- 4 & 12 & 44 & - & - & 1.21 & $\infty$ & $1.8: 0.42$ & - \\
\hline \multicolumn{2}{|r|}{$"$} & $A-5$ & 12 & 61 & - & - & 1.29 & $\infty$ & $1.8: 0.42$ & - \\
\hline \multicolumn{2}{|r|}{$"$} & A- 6 & 12 & 4 & 42 & - & 1.20 & $\infty$ & $1.8: 0.84$ & - \\
\hline \multicolumn{2}{|r|}{$"$} & A- 7 & 12 & 20 & 49 & - & 1.34 & $13 \sim \infty$ & $1.8: 0.84$ & - \\
\hline \multicolumn{2}{|r|}{$"$} & $A-8$ & 12 & 9 & 6 & 37 & 1.25 & $6 \sim 12$ & $1.8: 0.20$ & 2 \\
\hline \multicolumn{2}{|r|}{$"$} & A- 9 & 12 & 18 & 10 & 34 & 1.27 & $2 \sim 2$ & $1.8: 0.20$ & 2 \\
\hline \multicolumn{2}{|r|}{$"$} & A-10 & 12 & 18 & 21 & 28 & 1.31 & $0.6 \sim 0$ & $1.8: 0.20$ & 3 \\
\hline \multirow[t]{5}{*}{ 水 } & \multirow{5}{*}{$\begin{array}{l}\text { 川台 } \\
\text { " } \\
\text { " } \\
\text { " }\end{array}$} & B- 1 & 12 & - & - & - & 1.20 & $\infty$ & $1.8: 0.1$ & - \\
\hline & & B- 2 & 12 & 21 & 20 & 15 & 1.30 & $4.9 \sim \infty$ & $1.8: 2.0$ & 3 \\
\hline & & B- 3 & 12 & 22 & 20 & 3 & 1.30 & $\sim \infty$ & $1.8: 2.0$ & - \\
\hline & & B- 4 & 12 & 14 & 7 & 21 & 1.30 & $1.0 \sim 5$ & $1.8: 4.76$ & 2 \\
\hline & & B- 5 & 12 & - & - & - & 1.25 & $1.7 \sim \infty$ & $1.8: 0.1$ & - \\
\hline \multirow[t]{5}{*}{ 手 } & 賀 沼 & $A-11$ & 4.5 & - & - & - & 1.14 & $5.3 \sim \infty$ & $0.8: 0.1$ & - \\
\hline & $"$ & A-12 & 4.5 & - & - & - & 1.13 & $\infty$ & $0.8: 0.1$ & - \\
\hline & $"$ & $A-13$ & 4.5 & 48 & - & - & 1.20 & $4.3 \sim \infty$ & $0.8: 0.42$ & - \\
\hline & $"$ & A-14 & 4.5 & 69 & - & - & 1.29 & $12 \sim \infty$ & $0.8: 0.42$ & - \\
\hline & $"$ & A-15 & 4.5 & 28 & 41 & - & 1.31 & $0.3 \sim 0.3$ & $0.8: 0.84$ & 3 \\
\hline
\end{tabular}

形態 1 : 泥膜形成, 形態 $2:$ 中間状態, 形態 $3:$ 貫入状態

（b）泥膜形成実験総括表

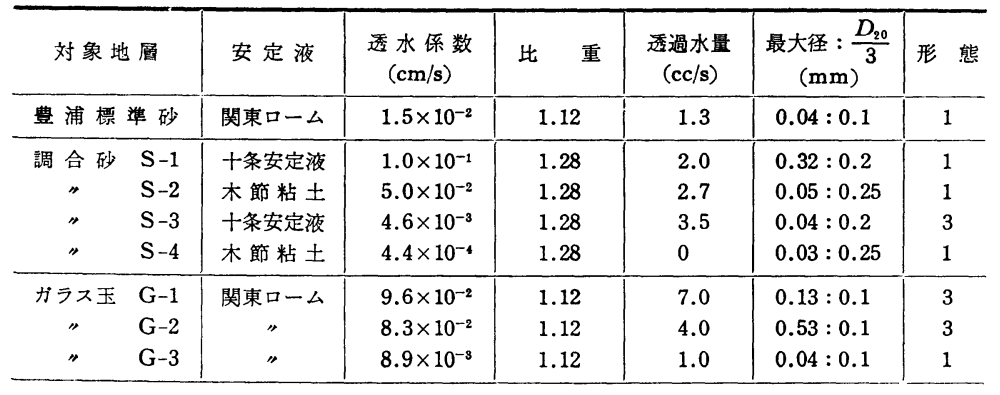

膜は，泥水圧の増加により，緻密な 透水性の低いケークとなり，水圧の 大部分を負担する有効な膜として作 用する。

一方，貫入の場合，低圧で貫入状 態のとき, 泥水圧を高めると貫入長 の増加，または逸水を生ずる．泥水 の粘性によるバランスであるから， 圧力の上昇に対して, 粘性による摩 擦長の延長で対抗する.それゆえ， 貫入状態は圧力に対して不安定なも のとなる.

d） 泥膜形成時間と泥水シールド 機械

泥水シールド工法に対する疑問点 の一つは, カッター・ビットの回転 切削の間に，はたして泥膜が形成さ れるかという問題である. シールド 機械の面板は，直径の大小により $0.7 \sim 3.0$ 回/分と回転数は変わる が, ビット取付け箇所数の大小から 平均すれば，同一箇所を再掘削する 時間間隔は約 10 15 秒である.

一方, 泥膜形成の場合，前記実験 から有効な泥膜の形成時間は $1 \sim 2$ 秒であり，また，中間状態の場合で も 2 4 秒後には有効な泥膜が形成 されるので，ある間隔で切削されて も十分に泥膜は形成される.

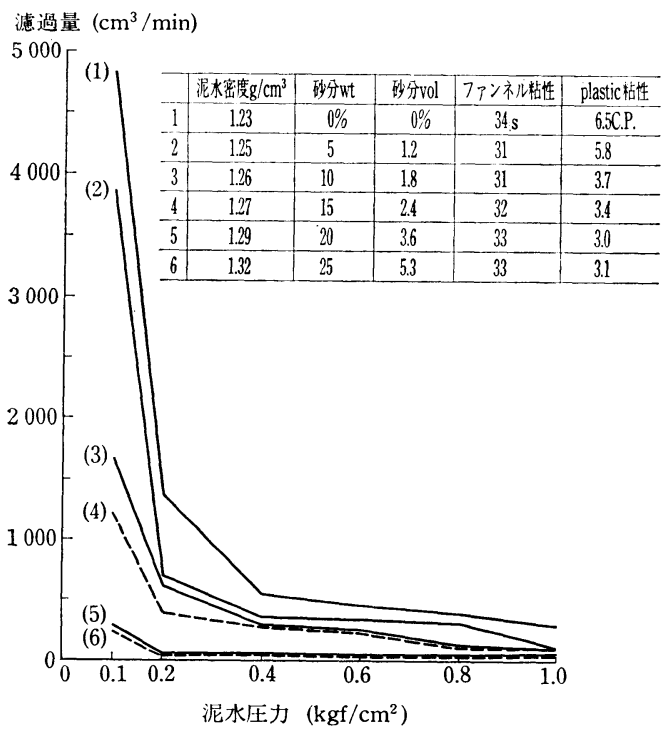

図一12 泥水圧と沪過量の関係
他方, 貫入状態は前記のごとく圧力に対して不安定な 状態であるから，この状態になるような泥水の使用は極 力避けるべきである．しかしながら，貫入状態で切羽を 保持するとき, 仮に 10 秒間隔で切削されてもシールド の掘進速度を $30 \mathrm{~mm} / \mathrm{min}$ とすれば, 10 秒ごとに深さ 5 $\mathrm{mm}$ の切削を受けるにすぎない，貫入長はこれより長 く, $5 \mathrm{~mm}$ 程度の貫入バランスは即座に回復すると思わ れる，それゆえ，貫入の場合も掘削中バランスを失うこ とがない。

\section{e） 泥水の濃度}

泥水中の水は沪材を通過し，土粒子固形分は沪材表面 に滞留泥膜を形成する. それゆえ, 高濃度泥水は単位体 積当たりの含有固形物量が多く, 稀薄泥水に比較して目 づまり効果も早く，泥膜形成の時間も短い。この点か ら, 泥膜形成には濃度の高い泥水が有利である.

表一2 に示すごとく沈降ベットの透過試験によって, 高濃度泥水のベットが沪過量も少なく，良好な泥膜が形 成されることが明確となった，沈降ベットの密度は，土 
粒子比重 2.68 で, 初期泥水密度 $1.11,1.19,1.30 \mathrm{~g} / \mathrm{cm}^{3}$ のときそそれぞれ $1.193,1.233,1.337 \mathrm{~g} / \mathrm{cm}^{3}\left(\times 10^{3} \mathrm{~kg} /\right.$ $\mathrm{m}^{3}$ ) となる. これからも高濃度泥水ほど良好な泥膜が形 成されるといえる. 現時点では, 有効な泥膜形成に必要 な濃度を求める理論的な方法がなく, 実験または経験的 に決定せざるを得ない。

\section{f）実験值と現場測定值の比較}

泥膜の有効度は透水量により判定される. 十条泥水 シールド現場の掘削停止中の平均全切羽面逸水量は, 作 業交代時 (1 1.5 時間) $0.38 \mathrm{~m}^{3} / \mathrm{h}$, 日曜日（24 時間） $0.21 \mathrm{~m}^{3} / \mathrm{h}$ であり, 測定值は $0 \sim 1.3 \mathrm{~m}^{3} / \mathrm{h}$ の範囲に分布 した. 一方, 現場発生砂䃯土の大型モールド長時間試験 の結果から, 切羽断面を初期 1 時間の沪過量, スキンプ レート面を長時間汇過量として計算すると $0.96 \sim 0.98$ $\mathrm{m}^{3} / \mathrm{h}$ となった. すなわち, 実験值は実績中の悪い方の 值に近く,また, これは大型モールド試験の有用性を示 している.

\section{(3) 土粒子保持力}

Müller-Kirchenbauer は地下水圧と泥水圧がバランス するとき，切羽表面の土粒子を泥水のせん断強度で保持 し得ることを実験より導いた ${ }^{13)}$. Weiss は球形粒子に 対する液体の粘性抵抗を考虑し, 直径 $d_{s} \mathrm{~cm}$ の粒子が せん断強度，すなわち, イールド・バリュー $\bar{\tau}_{F}\left(\mathrm{gf} / \mathrm{cm}^{2}\right)$ の泥水中を落下しない条件として次式を遒いた ${ }^{14)}$.

$$
d_{s} \leqq \frac{3}{2} \cdot \frac{x \cdot \bar{\tau}_{F}}{\left(\rho_{s}-\rho_{L}\right) \cdot g}
$$

ここで, $\rho_{s}$ は土粒子密度 $\left(\mathrm{g} / \mathrm{cm}^{3}\right), g$ は重力加速 $(\mathrm{cm} /$ $\mathrm{s}^{2}$ ) である. 粒子径 $2 \mathrm{~mm}$ 以上のときは乱流となり本式 は成立しない。

Müller-Kirchenbauer は Weiss の限界粒子径 $d_{c}$ と 地層の粒子径加積曲線の $d_{15}$ を実験より関係付け

$$
d_{15} \leqq 8 d_{c}
$$

のとき, 限界径 $d_{c}$ を保持する泥水は切羽全土粒子の落 下を防止すると結論した. なお式 (2) で左辺と右辺が等 号のとき $d_{s}=d_{c}$ となる.

泥水のイールド・バリニーによる切羽土粒子の保持は 簡単な砂箱試験で観察することができる. 箱の中央に仕 切りを置き，両側に砂および泥水を入れ，仕切りを引き 抜くと泥水が適当なものであれば土砂の崩壊を起こさな い. 圧力差が微小で泥膜は形成されないと思われ, 切羽 の保持は泥水のイールド・バリューによるものと推定さ れる.

\section{（4）泥水標準示方の決定}

a） 粒径配合の決定

掘削される地山の粒度分布を調查し, 粒径加積曲線よ
り $d_{20}$ の粒径を決定する. 地層は変化するから 最大の $d_{20}$ を取る. $d_{20} / 3$ を泥水土粒子の最大粒子径とする. この最大径から無数の粒度分布が得られるが, 均等係数 の大きいスムーズな曲線の配合を選ぶ. 元来試験により 最も適切な配合を決定するのが最良の手段である. しか し,この試験は設備と手間を必要とし, もし, 経験的デ ータがあればそれを参考にして配合を決定しても差し支 えない.

標準配合が決定したら，施工中の配合管理を十分に行 う必要がある. 良好な泥膜形成には適切な粒径配合が必 須の条件である. 粒径配合管理, 泥水の処理再調合は困 難な仕事であるが，泥水シールド工法を成功させるため の第 1 の条件である.

\section{b）泥水濃度の決定}

同一配合のとき，濃厚な泥水は希薄な泥水により良質 の泥膜を形成する. 掘削土粒子を保持する濃度も必要で ある. また, 施工中泥水圧の変動により, 泥水圧と地下 水圧が接近したとき, 切羽粒子の崩壊防止にある程度の せん断強度をもつことが望ましい. 試験により有効な泥 膜を形成する濃度を決定すべきであるが, 試験によらな い場合は, 一つの目安として, Müller-Kirchenbauerの 方法により地層中の $d_{15}$ の最大值を調査決定し， $d_{15}$ よ りWeiss の限界土粒子径 $d_{c}$ を式 (3) 上り求め, 式 （2）より泥水のイールド・バリュー $\bar{\tau}_{t}$ を求める. $\bar{\tau}_{t}$ が true Bingham yield Value である泥水濃度を決定する。

\section{4. 掘削吾の測定}

これまでは, 実験室の技術者の立場で論理を展開して きたが, 目的は固有の特性を有する現場の効果的な施工 にあり，試料を提供する現場とこれを解析する実験室と は, 互いにフィードバックし有機的な関係を維持しなけ ればならない，また，相似則の見地から現場と実験室は 各スケール大, 小の模型とみなすことができる. しかし ながら，標本としての役割を果たすスケール大の模型た る現場は, 直視による解析が不可能で別法に頼らなけれ ばならない，以下に統計学的手法による現場の掘削管理 について述べる.

\section{(1) 掘削量測定式}

泥水シールド工法において, 掘削中の切羽状態を常時 管理するには, 輸送される送排泥水量を測定し, その量 から掘削状態を識別することである，泥水量測定には， 単位当たりの流量を測定する方法, 土（土粒子十水）の 質量を測定する方法, および土粒子の質量を測定する方 法とがある. 図一13 に切羽の正常時および崩壊時の状 態を図示する。 
A. 流量測定法

単位時間当たり正常 時の送排泥流量をそれ ぞれ $Q_{0}, Q_{1}$ とし, 掘 削容量を $V_{R}$ とする と

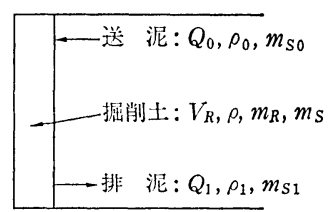

正常掘削状態

$$
Q_{1}-Q_{0}=V_{R}
$$

次に, 崩壊時の送排泥 流量を $Q_{0}{ }^{\prime}, Q_{1}{ }^{\prime}$, 崩壊 体積を $V_{R}{ }^{\prime}$ とすると， 崩壊した土は排泥され 崩壊空洞部には泥水が 送泥されるので

$$
\begin{aligned}
& Q_{0}{ }^{\prime}=Q_{0}+V_{R^{\prime}} \\
& Q_{1}{ }^{\prime}=Q_{0}+V_{R}+V_{R^{\prime}} \\
\therefore & Q_{1}{ }^{\prime}-Q_{0}{ }^{\prime}=V_{R} \ldots \ldots . .
\end{aligned}
$$

すなわち，流量測定法は崩壊検知能力 0 である.

B. 土の質量測定法

この場合, 正常時の送・排泥水密度を $\rho_{0}, \rho_{1}$, 掘削土 の質量を $m_{R}$ とすれば

$$
Q_{1} \rho_{1}-Q_{0} \rho_{0}=m_{R}
$$

いま, 土の質量 $m_{R}{ }^{\prime}$ だけ崩壊したとき, 土の密度を $\rho$ とすれば

$$
\begin{aligned}
& Q_{0}{ }^{\prime} \rho_{0}=Q_{0} \rho_{0}+\frac{m_{R}{ }^{\prime}}{\rho} \cdot \rho_{0} \\
& Q_{1}{ }^{\prime} \rho_{1}{ }^{\prime}=Q_{0} \rho_{0}+m_{R}+m_{R}{ }^{\prime} \\
\therefore & Q_{1}{ }^{\prime} \rho_{1}{ }^{\prime}-Q_{0}{ }^{\prime} \rho_{0}=m_{R}+m_{R}{ }^{\prime}\left(\frac{\rho-\rho_{0}}{\rho}\right) .
\end{aligned}
$$

すなわち，土の質量測定法は $\rho-\rho_{0} / \rho$ の崩壊検知能力 である．上式は崩壊部の土の代わりに泥水が置き換えら れ, 土の密度 $\rho$ と泥水密度 $\rho_{0}$ との差だけの質量が検 知されることを表わしている.

C. 土粒子質量測定法

正常時の単位時間当たり掘削土粒子質量 $m_{s}$ は次式で 計算できる。

$$
m_{s}=\frac{\rho_{s}}{\rho_{s}-1}\left\{Q_{1}\left(\rho_{1}-1\right)-Q_{0}\left(\rho_{0}-1\right)\right\}
$$

ここで， $\rho_{s}$ は土粒子の密度である．単位時間の送泥土 粒子質量を $m_{s 0}$, 排泥土粒子質量を $m_{s 1}$ とすれば

$$
m_{s 1}-m_{s 0}=m_{s}
$$

次に, 崩壊時の単位時間の送泥土粒子質量を $m_{s 0}{ }^{\prime}$, 排 泥土粒子質量を $m_{s 1}{ }^{\prime}$ ，崩壊部の土粒子質量を $m_{s}{ }^{\prime}$ とす ると， $m_{s}^{\prime}$ はすべて排泥され送泥水と置き換わるので， 図一13 を参照して

$$
\begin{aligned}
& m_{s 0}{ }^{\prime}=m_{s 0}+\frac{m_{s}{ }^{\prime}}{\rho_{s}}(1+e) \rho_{s} \frac{\rho_{0}-1}{\rho_{s}-1} \\
& m_{s 1}{ }^{\prime}=m_{s 0}+m_{s}+m_{s}{ }^{\prime}
\end{aligned}
$$

表一5 崩壊検知能力の比較

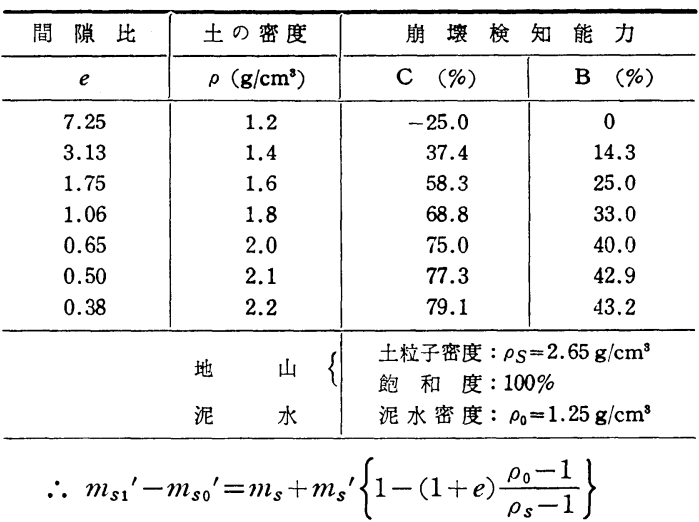

すなわち, 土粒子質量測定法は括弧内の崩壊検知能力が あり, その減少率, 土粒子密度, 泥水密度は間隚比の関 数である. Bおよび $\mathrm{C} の$ 検知能力の比較の一例として， 泥水密度 $1.25 \mathrm{~g} / \mathrm{cm}^{3}\left(1250 \mathrm{~kg} / \mathrm{m}^{3}\right)$ の場合を 表一5 に示 す. 以上の結果から土粒子質量測定法が最も優れている といえる。

\section{（2）測定式の精度}

掘削土粒子質量は, 送排泥水の流量および密度を測定 し式 (8) より計算される. 測定には精度の点から $r$ 線 密度計および電磁流量計が用いられる．鈴木によれば， この両者の測定值はほぼ 一様分布すると考えられ る ${ }^{15)}$. 4 個の測定值を組 み合わせた式 (8) の計算 值は正規分布に近くなる と考えられる．現場測定 值のヒストグラムの一例 を図一14 に示す. 地質 がほぼ均一である区間で は，測定計算值 $m_{s}$ はほ ぼ正規分布する。

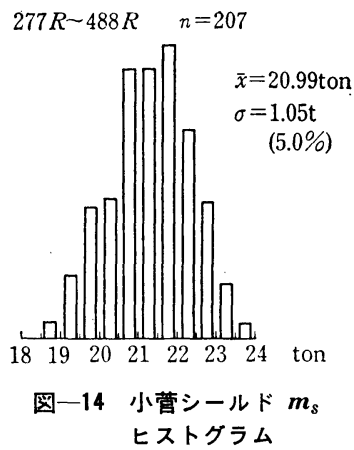

\section{5. 掘削管理}

\section{（1）地層のグループ分け}

測定值誤差計算は, 地層がほぼ同一であることを前提 として行われた。しかし，実際の地層は均一でなく，そ れゆえ，測定值を統計的に取り扱うために，ほぼ均一と 認められる区間に分割することが必要である．この方 法の一例として，西川ロシールドの場合を図一15 に示 す. 図の上段はボーリング位置により，下段は測定值か ら統計的によい結果が出るよう区分してある。この両者 
ボーリング位置による区分

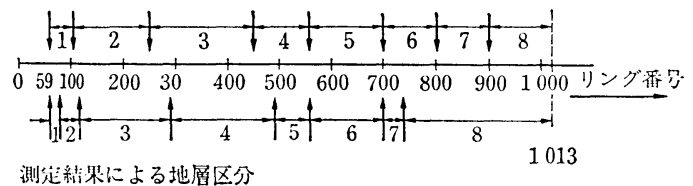

図一15 グループ分け（西川ロシールドの場合）

表一6 ボーリング位罳による区分によった各グループの 算平平均值と測定值の標準偳差

\begin{tabular}{c|r|c|r|r|r|r}
\hline 番号 & リンク番号 & $\begin{array}{c}\sum_{(\mathbf{t})} x \\
(\text { (個) }\end{array}$ & $\begin{array}{c}\bar{x} \\
(\mathbf{t})\end{array}$ & $\begin{array}{c}\sigma_{n} \\
(\mathbf{t})\end{array}$ & $\begin{array}{c}\sigma_{n} / \bar{x} \\
(\%)\end{array}$ \\
\hline 1 & $59 \sim 104$ & 132.24 & 43 & 3.075 & 0.225 & 7.3 \\
2 & $105 \sim 248$ & 195.97 & 62 & 3.161 & 0.133 & 4.2 \\
3 & $249 \sim 450$ & 561.07 & 190 & 2.953 & 0.145 & 4.9 \\
4 & $351 \sim 555$ & 312.25 & 101 & 3.092 & 0.097 & 3.1 \\
5 & $556 \sim 700$ & 437.00 & 130 & 3.362 & 0.074 & 2.2 \\
6 & $701 \sim 799$ & 314.04 & 95 & 3.306 & 0.115 & 3.5 \\
7 & $800 \sim 899$ & 306.95 & 91 & 3.373 & 0.106 & 3.1 \\
8 & $900 \sim 1031$ & 337.33 & 100 & 3.373 & 0.090 & 2.7 \\
\hline
\end{tabular}

表一7 測定値よりの区分によった各グループの 澌年平均值と測定值の標準偏差

\begin{tabular}{l|r|r|r|r|r|r}
\hline 番号 & リンケ番号 & $\begin{array}{c}\sum x \\
(\mathbf{t})\end{array}$ & $\begin{array}{c}n \\
(\text { 個 })\end{array}$ & $\begin{array}{c}\bar{x} \\
(\mathbf{t})\end{array}$ & $\begin{array}{c}\sigma_{n} \\
(\mathbf{t})\end{array}$ & $\begin{array}{c}\sigma_{n} / \bar{x} \\
(\%)\end{array}$ \\
\hline 1 & $59 \sim 68$ & 34.80 & 10 & 3.480 & 0.074 & 2.1 \\
2 & $69 \sim 116$ & 127.03 & 43 & 2.954 & 0.064 & 2.2 \\
3 & $117 \sim 290$ & 309.10 & 97 & 3.186 & 0.097 & 3.0 \\
4 & $291 \sim 489$ & 541.70 & 186 & 2.912 & 0.090 & 3.1 \\
5 & $490 \sim 555$ & 198.35 & 63 & 3.148 & 0.070 & 2.3 \\
6 & $556 \sim 702$ & 443.67 & 132 & 3.361 & 0.074 & 2.2 \\
7 & $703 \sim 735$ & 99.24 & 31 & 3.201 & 0.086 & 2.7 \\
8 & $736 \sim 1031$ & 852.47 & 253 & 3.369 & 0.099 & 2.9 \\
\hline
\end{tabular}

の統計処理の結果を 表一6, 表一7 に示す. 表一6 は地 質調查からボーリング地点の掘削土粒子質量を計算し, 2 点間を平均化し, その值を真值として測定值と比較し た. 表一7 は测定值の組合せの試算から標準偏差が最小 になるよう求めた. 表一6 の結果が表一7 に比べて劣 るのは地質調查の精度, 地質縦断図作成上の不合理性, シールド機械の寸法精度の悪さのためであると考えられ る. それゆえ, 測定值によるグループ分けの方法は真值 を求め得ないが, 上記誤差原因を取り除き, グループ内 での誤差量を少なくすることが結論される.

それぞれが, 別のグループに属する 2 個の測定值の関 係を図一16により説明する. 地層の変化で別のグルー プ 2 に属する点 $\mathrm{p}$ が，グループ 1 の範囲を $x \pm 2 \sigma$ とし たため， 2 に属するにもかかわらず 1 に属すとの判断の 過誤を犯す. 逆にグループ 1 に属する点 $\mathrm{p}^{\prime}$ が $x \pm 2 \sigma$ の範囲外にあるため, グループ 2 に属すとの判断の過誤 を犯す. 判断の過誤を小さくするために測定值の精度, すなわち, 標準偏差 $\sigma$ を小にする必要がある. $\sigma$ が大き いとき地質の変化と測定值の正規変動を判別できず, 後 述のごとく切羽崩壊の識別を困難にする.

すなわち, 測定值の精度向上はきわめて重要である.

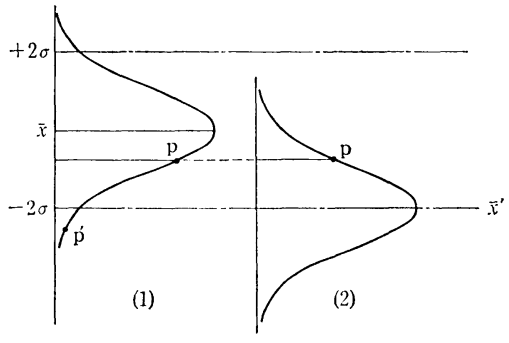

図-16 測定值の分布

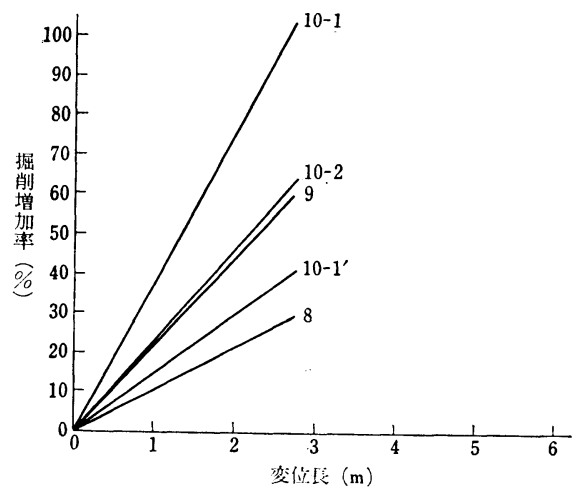

変化前の地層 $\rightarrow$ 变化後の地層

8. 沖積ンルト層 $\rightarrow$ 洪皘砂層 (手賀沼)

9. 沖積 細砂層 $\rightarrow$ 沖積ンルト首 (手賀沼)

10-1 沖積ンルト層 $\rightarrow$ 沖皘細砂 (手賀沼) 10-2 沖積ンルト層，沖皘細砂 (手賀沼)

図一17地層変移過程での掘削量の変化の実例

流量計および密度計の精度向上, 計器の有効な使用, そ して適切なる流量一掘進速度一泥水密度の組合せにより精 度の向上が図られる。

\section{（2）地層の変化と切羽崩壊の判別}

あるグループから他のグループへの変化は，地層変化 と切羽崩壊の場合である. それゆえ, 土粒子質量測定值 による掘削管理は両者の区別がキーポイントとなる.

地層変化が測定值の変動として現われる状況は, 断層 で, かつ，断層面が掘削面と平行である場合は別とし て，一般的には数リングで変わる. いくつかの例を図一 17 に示す. 実線で示した $8,9,10$ は間陌比 $e=3.60$, 士の密度 $\rho=1.38 \mathrm{~g} / \mathrm{cm}^{3}\left(1380 \mathrm{~kg} / \mathrm{m}^{3}\right)$ の有機質の超軟弱 シルトからの変化の場合である. いま, 超軟弱シルトの 代わりに軟らかい沖積シルト $(e=1.80)$ とすれば, 101 は 10-1' となる. 特殊の場合を除き, 一般的に実績 データの最大值は, 全断面変移で $17 \% / \mathrm{m}$, 一部分変移 で $10 \% / \mathrm{m}$ ，また，変移長は $2.70 \sim 6.00 \mathrm{~m}$, リング数 で 3〜6R である. 図一18 は数多くのボーリングデー タに基づき地層が 4 リングで全断面変化した場合に掘削 量の変化を試算したもので, それを実線で示す.

切羽崩壊時測定值の変動は, 崩壊の形態によって変 


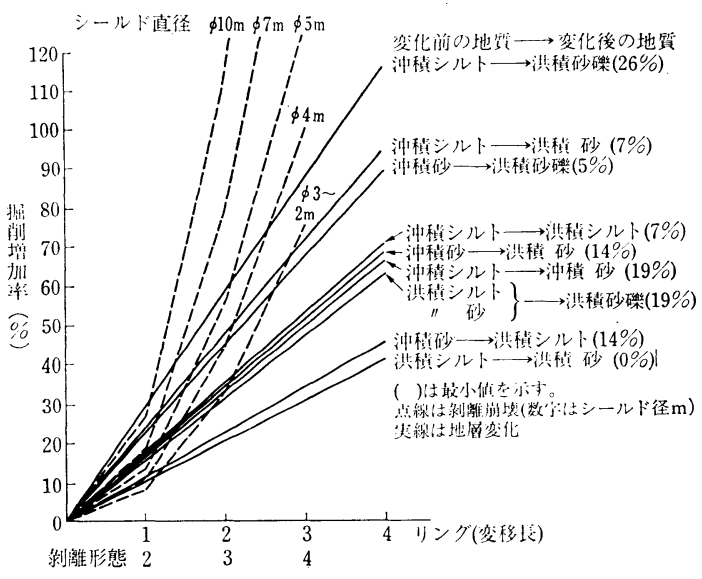

図一18地層変化と剥離崩壊の比較

わる. Proctor お よび White のい $5^{16)}$ 液状流動, ま たは流動地山の場 合, 切羽崩壊が起 これば 1 リング掘 削量の何百倍にも なり, 後述のリン グ内管理により明 確に判別が可能で ある. 次の剝離す る地山の場合, 剝 離地山とは支保工 を建て込み, 裏込

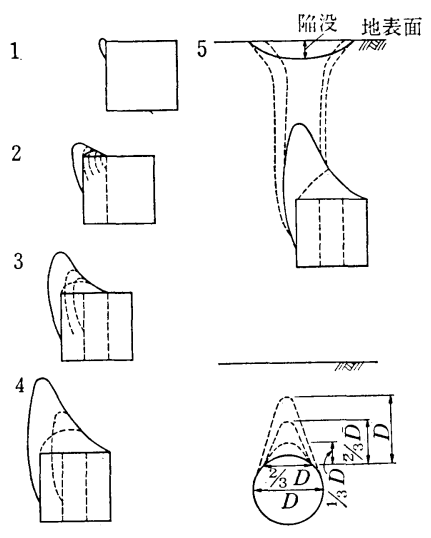

図一19 剝離形態
注入をするまでの間に土の塊とか剝片が落下し，しだい に崩壊に至るような地層をいうが，剝離形態は圧気シー ルドでの経験から，図一19の経過をたどると仮定され る. この変化状況を剝離形態 $2,3,4$ についてシールド 直径別に 図一18 に点線で示す.

地層変化は一般に地質縦断図で事前に予知できる。 た，それ以外に排泥処理された掘削土の粒径および色， カッター・トルク, ジャッキの推進速度および推力によ り間接的に地層変化を推定できる.また，さらに別の補 助的手段として，図一19 の 1 および 2 の状態の有無を 確認するため, クラウン部の地山に貫入棒を挿入し, そ の貫入抵抗值を測定する.これら補助的判別法の併用は 有効である.

図一18の点線および実線を比較すれば， $4 \mathrm{~m}$ 以上の 直径の場合これら補助的判別法を用いることなしに，剝 離形態 3 に至る以前に崩壊状態を判別し得る. 直径 2 $3 \mathrm{~m}$ の場合でも形態 2 3 の間に掘削量で約 $25 \%$ の増 を示し, 補助的判別法を併用すれば崩壊の有無を判別し 得るであろう。

\section{（3）リング間の掘削管理}

リング間のデータ管理は, JIS Z 9021 管理図法にな らった考え方を使うので，この掘削管理と JIS との相 違を説明する. 品質管理では管理される原母集団に変動 があり, 測定する計器の精度は微少として無視される. 一方，掘削管理では原母集団である地山も変化し，ま た, 測定計器の誤差も無視し得ない. しかしながら, 地 山が均一であるとき測定值は正規分布する．それゆえ， 両者の関倸は逆であるが, 正規分布する点に着目して管 理図法にならった考え方により，リング間のデータ管理 が可能なはずである.

管理図法では，当初の予備データから管理限界を定め るが，泥水シールドでは掘削開始時には予備デー夕は皆 無である. それゆえ，独自の方式として $2 \sigma$ 限定法と 一元配置分散分析法を開発した.リング間の掘削管理は 新しい測定值が直前のグループに属するか否かを判定し て, 同一グループであれば切羽状況は正常であり, 他グ ループに属すると判定されれば，その変化の勾配から地 層変化と切羽崩壊を判別する方法である.

$2 \sigma$ 限定法は, 目標とする管理限界として標準偏差値 $\sigma_{T}$ を始めに定める. いま, 新しい測定值 $m_{s, n+1}$ が得 られれば, 直前のグループ $N$ の平均值を $\bar{m}_{s, n}$, 標準 偏差 $\sigma_{n}$, 範囲 $R_{i}=m_{s, n}-m_{s, n-1}$ とすると

$$
\begin{aligned}
& \bar{m}_{s, n}-2 \sigma_{n} \leqq m_{s, n+1} \leqq \bar{m}_{s, n}+2 \sigma_{n} \\
& \sigma_{n+1} \leqq \sigma_{T} \\
& R_{n+1} \leqq 2.83 \sigma_{n}
\end{aligned}
$$

を満足するとき $m_{s, n+1}$ はグループ $N$ に属し，切羽は 正常であると判定される. もしも属さないときは, 異常 点として所要の注意と対策が必要である. いま, 目標偏 差值 $\sigma_{T}=2.5 \%$ とすれば, 測定システムの最大誤差值 は前記 3.5 5 $\sigma$ から 9 12.5\% となり, この範囲に収 まるシステムを設備する必要がある.

一元配置分散分析法は, 測定值のグループ 分け（層 別）を統計的手法で行う. 本法は変数が 1 つのとき， 2 つのグループ間の変動の度合いと, グループ内の測定値

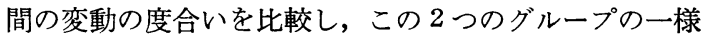
性を検討する手法である. 用いる $F$ 分布は $2 \sigma$ に対応 した片側確率 $2.5 \%$ の $F\left(\phi_{1}, \phi_{2}, 0.025\right)$ 数值表であ る.

図一20 はリング間の管理図であり，点線は一元配置 分散分析法, 実線は $2 \sigma$ 限定法を示し, 現在のところ 両者の優劣は決めがたい。

\section{（4）リング内の掘削管理}

液状流動または流動地山の崩壊は，1リング掘削中に 所定量の何十倍もの土砂を搬出する可能性がある．それ 


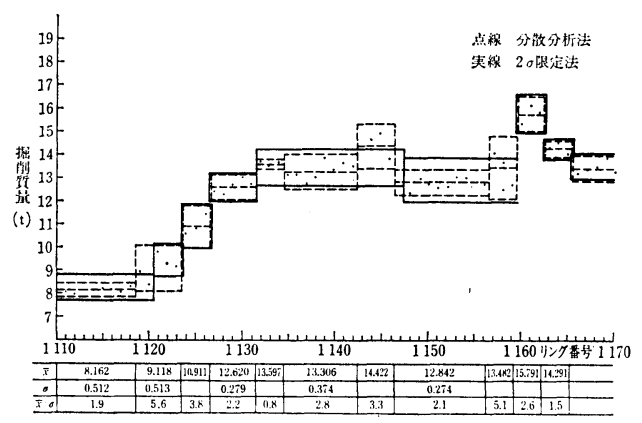

図一20 北千葉シールドリング間管理図

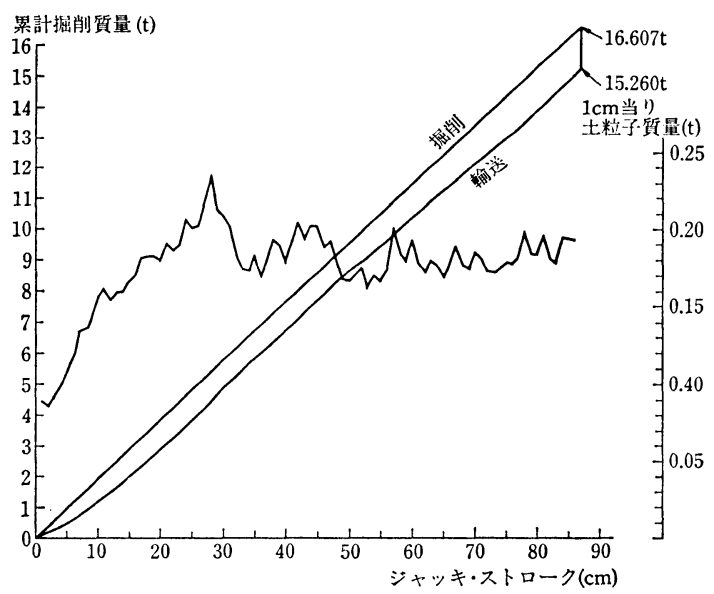

図一21手賀沼シールド $635 \mathrm{R}$ 掘削土粒子輸送図

ゆえ，1リング掘削中の掘削管理が必要である. 1 リン グの掘削量と測定值の関係を 図一21 に示す. 測定値は 輸送量であって切羽掘削量ではない.すなわち, 掘削初 期には掘削土砂はチャンバー内に停滞し, ある時間経過 後定常的に輸送され, 掘削停止後も停滞士砂は輸送され る.このパターンは共通のものであるが, 停滞量は地 質, 機械特性, 掘進速度, 流量, 泥水特性等種々の要素 によって決まる. 一例として, 手賀沼シールドの同一地 層グループの統計図を 図一22 に示す.

リング内の掘削管理は以上のことから次のごとく行う ことができる. リング間の掘削管理によりグループ分け された今リング直前の $n$ リングを含むグループを $N$ と する. グループ $N$ は $1 \sim n$ の $n$ リングで構成される. $n$ リング掘削完了後 1 n リングそれぞれの $1 \mathrm{~cm}$ ごと の累積輸送量を計算する。いま, 掘進長を $i \mathrm{~cm}(i=1$, $\cdots, 90)$ で表わし, $i \mathrm{~cm}$ の累積輸送量を $N$ グループに ついて統計計算する. その平均值を $\bar{m}_{i, n}$, 標準偏差を $\sigma_{i, n}$ とする. 図一23 のように $\bar{m}_{i, n}$ を $100 \%$ 表示し, $2 \sigma_{i, n}$ を管理限界線として表わす。いまリングすなわち $n+1$ リングの掘削開始とともに $1 \mathrm{~cm}$ ごとの累積輸送 量 $m_{i, n+1}$ を次の值で図中にプロットする.

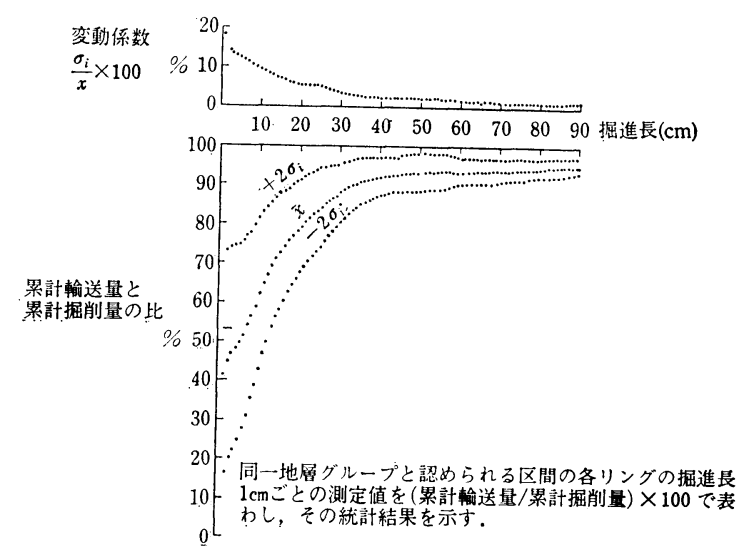

図一22 $1 \mathrm{~cm}$ ことの累計輪送旦と累計掘削量の比

$$
\frac{m_{i, n+1}}{\bar{m}_{i, n}} \cdots(14)
$$

この点が $2 \sigma_{i, n}$ の限界 線内にあれば, 掘削状態 は管理上安全側にあると 判定する. 図一23 は手 賀沼シールドの $786 R$ および $791 R$ の実積で ある。

\section{6. 結 論}

泥水シールド工法は透 水係数 $k=10^{-2} \mathrm{~cm} / \mathrm{s}$ 以 上の砂および砂䃯層に対 して不適切であろうとの 疑問があったが, 本研究 によって一応の解答が与 えられたと考える.さら に在来の経験的決定法に

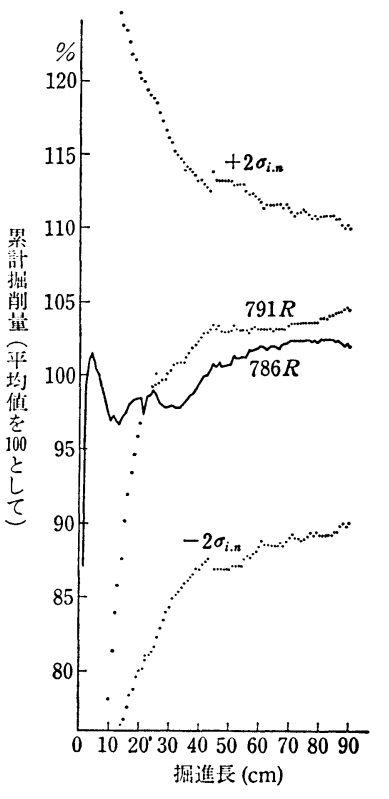

図一23 リング内管理図
よらない理論に基づいた泥水仕様の決定法が示され，ま た，合理的な掘削管理システムが提案された.

本研究で得られたおもな結論をまとめると次のごとく である.

（1）泥水は含有する粒子の形状寸法によりその特性 が決定され, 土粒子がフロック化するとき, 比較的㜊度 が薄くても強度ある泥水が得られる. それゆえ, 泥水密 度のみで泥水特性は決定されず, フロック性向む重大な 要素である.

（2） 泥水シールドの切羽面は 3 つの状態に分類され る. 泥膜形成の形態が最も重要であり, 泥膜は目ゔまり 効果により形成される. 泥水の最大土粒子径が地山の粓 径加積曲線の $D_{20} / 3$ より大きいことが目ゔまり効果を生 ずるための必須の条件である. 
（3）泥水濃度は粒子保持の点から必要なイールド・ バリニーをもつものであること. 一応の目安として Müller-Kirchenbauer の式を使うことができる.

（4）掘削量測定は土粒子質量測定法が最も優れてい る. 使用される測定システムは, その精度について十分 に検討する必要がある.

（5）掘削管理は測定值をほぼ同一地層にグループ分 けし，リング間およびリング内の掘削管理により行うこ とができる.ただし, 切羽崩壊が徐々に進行するときは 崩壊と地層変化の判別が困難であり, 補助的識別法が必 要である.

\section{参 文 献}

1) Greathead, J.H. : Apparatus for excavating tunnels, subway and shaft, イギリス・パテント No. 5665, 1884.

2) Veasey, D.J. : Bentonite tunnelling, Bulletin of the National Research Development Corporation, No. 45, 1977.

3）喜田大三：地中連続壁工法における安定液の調合と管理, 土と基礎, 昭和 48 年 1 月.

4) Roger, W.F. : Composition and Properties of Oil Wall Drilling Fluid, Gulf Publishing Company, 1963.

5) Boyes, R.G.H. : Structural and Cut-off Diaphragm Wall, Applied Science Publishers Ltd., London, 1975.

6）吉岡直哉, その他：均一スラリーの回分沈降に打ける諸
特性, 化学工学, 第 19 巻, 第 12 号, 1955 .

7) Shannon, P.T., et al : Batch and Continuous thickening, Industrial and Engineering Chemistry, Vol. 1, No. 1, 1962.

8) Michaeles, A.S. and J.C. Bolger : Settling rates and sediment Volumes of flocculated Kaolin suspensions, Industrial and Engineering Chemistry, Vol. 1, No. 1, 1962.

9）北浦嘉之, その他：凝集性懸濁液の粘度, 化学工学, 第 29 巻, 第 2 号, 1965.

10) Michaeles, A.S., et al : Permeability and Washing Characteristics of flocculated Kaolinite Filter Cake, Industrial and Engineering Chemistry, Vol. 6, No. 1, 1967.

11）後藤圭司, その他: 疑集性スラリーの沈降と堆積, 化学 工学, 第 32 巻, 第 11 号, 1968.

12) Yong, R.N. and B.P. Warkentin（山崎不二夫 - 山内豊 聡ほか訳) : 土質工学の基礎, 鹿島研究所出版会, 1974.

13) Müller-Kirchenbauer : Stability of slurry trench in inhomogeneous subsoil, 第 9 回国際土質基礎会議, session 3, 東京, 1977.

14) Weiss : Die standsicherheit flüssigkeitsgestutzter erdwünde, Bauingenieur-Praxis, Heft 70, Verlag Von Wiehelm Erust u Sohn, Berlin-München, 1967.

15）鈴木栄一：泥水システムの統計的分析と検討, 自然環境 科学研究所, 1977 .

16) Procter and White: Earth Tunnelling With Steel Supports, Commercial Shearing Inc., 1977.

(1981.5.19 - 受付) 